WARSZTATY Z GEOGRAFII TURYZMU

ISBN 978-83-7969-262-0 $\quad$ s. 295-311

http://dx.doi.org/10.18778/7969-262-0.19

Stanisław ERDAWLETOW

Żannat N. ALIJEWA

Uniwersytet im. Al-Farabiego w Ałmaty

Danagul M. MUKATOWA

Kazachski Narodowy Uniwersytet Pedagogiczny im. Abaja w Ałmaty

\title{
WSPÓŁCZESNY KAZACHSTAN - NOWY KIERUNEK NA ŚWIATOWYM RYNKU TURYSTYCZNYM
}

\section{Wstęp}

Rozwój turystyki w każdym kraju zależy od wielu czynników, spośród których jako ważne należy uznać: przepisy celne i wizowe państwa oraz stosunki z innymi krajami; regulacje prawne dotyczące sektora turystycznego; sytuację polityczną $w$ regionie (gdyż niewielu wypoczywających zaryzykuje obecnie podróż do kraju, gdzie sytuacja polityczna jest niestabilna); stan infrastruktury turystycznej, której stopień rozwoju jest istotnym wskaźnikiem atrakcyjności danego regionu czy państwa. Nade wszystko jednak ważną rolę dla państwa mającego być atrakcyjne dla turystów odgrywają walory turystyczne i rekreacyjne regionu oraz produkt turystyczny, który dany kraj może zaoferować. Aby produkt turystyczny regionu (państwa) mógł zaistnieć na arenie międzynarodowej, niezbędna jest reklama i promocja kraju jako destynacji turystycznej.

Pomimo złożonej sytuacji politycznej i gospodarczej konkretnego kraju czy regionu i różnorodnych trudności związanych ze światowym kryzysem 
ekonomicznym, turystyka na świecie rozwija się w określonym tempie. Rozwój turystyki dotyczy coraz większej liczby krajów i obszarów, a turyści nieustannie odkrywają nowe kierunki. Dla Kazachstanu szczególnie ważne jest, by nie pozostać na peryferiach światowego rynku turystycznego i wystąpić na nim z godną i konkurencyjną ofertą.

\section{Potencjał turystyczny i czynniki hamujące rozwój turystyki w Kazachstanie}

Kazachstan, posiadając znaczący potencjał, na rynku turystycznym zaistniał stosunkowo niedawno, nie wykorzystując odpowiednio czasu i posiadanych licznych zasobów. Jak wiadomo, na terytorium państwa znajduje się wiele cennych rezerwatów i parków narodowych, ponad 9 tys. zabytków archeologicznych i historycznych, setki zakładów leczniczych i uzdrowiskowych. Specjaliści szczególną uwage poświęcają północnej części Jedwabnego Szlaku, na którym już wiele setek lat temu miasta: Farab, Sajram, Taraz, Syganak, Sauran, Turkiestan, pełniły funkcję ważnych ośrodków handlowych. Historycy jako godne uwagi wymieniają pomniki historii, takie jak mauzoleum hodży Ahmada Jasawi pochodzące z końca XV w. i początku XVI w., mauzolea Ajsza-Bibi i Babadża-Chatun (X-XII w.), Karachana i Daudbeka oraz inne miejsca kultu, które pozwalają odkryć przed turystami nowe regiony. To tylko nieliczne przykłady, albowiem inne regiony Kazachstanu moga również poszczycić się bogatym dziedzictwem kulturowym i przyrodniczym. W obwodzie akmolskim znajduje się słynny kurort Burabaj, znane kompleksy przyrodnicze, jak m.in. Zerenda, Sandyktau, Jerejmentau, rezerwat korgałżyński. Są tam trzy narodowe parki przyrody - Burabaj, Kokczetaw i Bujratau.

Republika Kazachstanu, posiadając duży potencjał turystyczny, może zaoferować turystom uprawianie różnych form turystyki. Każdy z nich może wybrać albo turystykę pielgrzymkową, albo ekologiczną, sportową, uzdrowiskową itd.

Produkt turystyczny Kazachstanu, niestety, charakteryzuje niekorzystna specyfika. Podobnie jak produkt turystyczny wielu sąsiednich krajów, ma charakter sezonowy, co wskazuje na uchybienia w rozwoju turystyki. Podczas analizy rozwoju turystyki Kazachstanu wskazano także na inne problemy, które hamują rozwój turystyki wewnątrzkrajowej. Pierwszym z nich 
jest fakt, że w Kazachstanie, posiadającym bogate zasoby dla rozwoju turystyki i rekreacji, brakuje infrastruktury turystycznej spełniającej wymagania współczesnych podróżnych - dobrych hoteli, zróżnicowanych środków transportu, systemów telekomunikacyjnych i ogólnie dobrze rozwiniętej sfery obsługi, która stała się już normą dla turystów zachodnich. W Kazachstanie, na szczeblu państwowym, nikt nie zajmuje się poważnie i w sposób planowy rozwiązaniem tego problemu. Finansowanie turystyki dzisiaj, tak jak dawniej, odbywa się na zasadzie zbywania. W pogoni za nieuchwytnymi dziś petrodolarami, państwo traci potencjalne możliwości podźwignięcia gospodarki krajowej dzięki turystyce. Wiadomo, że inwestycje w infrastrukturę turystyczną zwracają się szybko. Trzeba nadmienić, że turystyka wewnątrzkrajowa w większości rozwiniętych turystycznie krajów daje od 30\% do $50 \%$ wszystkich wpływów z turystyki. Kazachstan ma dobre perspektywy rozwoju turystyki wewnątrzkrajowej, lecz dziś ma ona charakter głównie żywiołowy i niezorganizowany. Z powodu braku dostatecznej uwagi i braku dbałości ze strony państwa, sektor turystyczny otrzymuje zbyt mało środków, w konsekwencji czego ciągle niszczeje infrastruktura, uszczerbku doznają pomniki przyrody, kultury i historii.

Jedną z podstawowych przyczyn, która jest przeszkodą w rozwoju turystyki w Kazachstanie, jest niedostateczne wsparcie biznesu turystycznego przez państwo. Bez niego turystyka nie może stać się dochodową gałęzią gospodarki. Obowiązująca ustawa O działalności turystycznej w Republice Kazachstanu nie obejmuje wszystkich aspektów związanych z rozwojem turystycznym i sprowadza się wyłącznie do regulacji stosunków finansowych, walutowych i licencyjnych w sferze turystyki międzynarodowej, określenia podstawowych praw i obowiązków turystów przyjeżdżających do Kazachstanu i wyjeżdżających z niego. O turystyce krajowej, w tym także uzdrowiskowo-sportowej, w ustawie nie ma ani słowa. $\mathrm{W}$ istocie prawo ukierunkowane jest na rozwój turystyki wyjazdowej. Obowiązywanie takiego przepisu w dłuższej perspektywie czasowej zgubnie wpłynie na rozwój aktywnego wypoczynku Kazachów (Zakon... 2001).

Na pozycji gospodarki turystycznej w Kazachstanie niekorzystnie odbiła się także bezplanowa reorganizacja organów zarządzania państwem, szczególnie odpowiadających za rozwój turystyki, cięcia finansowe środków przeznaczonych na ich utrzymanie oraz liczne przesunięcia kadrowe.

Tu pojawia się ważna kwestia dotycząca kompetentnej administracji turystycznej na szczeblu państwowym. Aktualnie jest to Komitet Przemysłu Turystyki przy Ministerstwie Przemysłu i Nowych Technologii. Należy jed- 
nak podkreślić, że w ciągu 22 lat istnienia niepodległego państwa organ ten znajdował się w dziewięciu różnych ministerstwach kraju, co także negatywnie wpłynęło na rozwój turystyki krajowej.

Czynnikiem hamującym rozwój turystyki w Kazachstanie jest także praktycznie zupełny brak naukowych podstaw działalności turystycznej. Pilnie potrzebne są odpowiednie struktury naukowe, które zajmowałyby się kwestiami kompleksowego prognozowania rozwoju i organizacji terytorialnej turystyki, prowadziły prace dotyczące walorów turystycznych i rekreacyjnych, opracowywały naukowe podstawy organizacji turystyki, w tym dla poszczególnych jej form oraz zarządzania nimi.

Naukowcy kazachstańscy oraz liczni działacze społeczni wielokrotnie podejmowali problem utworzenia republikańskiego instytutu naukowo-badawczego turystyki przy narodowej administracji turystycznej lub gabinecie ministrów oraz utworzenia "laboratoriów turystycznych" przy wiodących szkołach wyższych kraju, na których mogłoby spoczywać rozwiązywanie problemów dotyczących rozwoju turystyki w Kazachstanie (ERDAWLETOW $i$ in. 2013).

Główną przyczyną niskiej jakości produktu turystycznego oferowanego turystom zagranicznym w centrach obwodów jest brak hoteli odpowiedniej klasy. Istniejąca baza hotelowa jest w 80\% zniszczona (zdekapiatalizowana), ponieważ większość obiektów została wybudowana w latach 60. ubiegłego wieku i liczy bez mała 60 lat. Oprócz bazy noclegowej odnowy wymagają baza gastronomiczna i transportowa.

Liczne powszechnie znane międzynarodowe firmy badawcze i konsultingowe, szczegółowo zapoznawszy się z kazachskimi projektami, oceniły je dość krytycznie. Podstawowe zastrzeżenia dotyczą liczby miejsc noclegowych w kraju, która od 2011 r. do 2012 r. zmniejszyła się o 13,6\% oraz liczby turystów zagranicznych, która w tym samym czasie zmniejszyła się o 16,2\%. Podstawowe przyczyny tego zjawiska to: wysokie ceny produktów turystycznych, niska jakość obsługi, niekonkurencyjność produkcji krajowej, niski poziom wiedzy o Kazachstanie poza jego granicami, słabo rozwinięta infrastruktura i wiele innych.

Kazachstan jako kierunek turystyczny jest praktycznie nieznany na światowym rynku turystycznym, pomimo faktu, że jego terytorium od dawna zapewniało łączność między Chinami a Europą, na przestrzeni wieków było świadkiem wielu historycznych wydarzeń na tej części Szlaku Jedwabnego, która przebiega przez obszar państwa. Stworzenie pozytywnego wizerunku turystycznego kraju to przedsięwzięcie niemożliwe do zrealizowania w krót- 
kim czasie. W celu wprowadzenia Kazachstanu na arenę międzynarodową i osiągnięcia sukcesów w turystyce światowej konieczne jest przedsięwzięcie wielu środków. Bez wątpienia, w pierwszej kolejności jest to uczestnictwo organizacji turystycznych kraju w międzynarodowych targach, zjazdach, konferencjach, w tym także organizowanych przez UNWTO. Równie ważna jest realizacja tego typu przedsięwzięć na terytorium Republiki Kazachstanu.

Można więc skonstatować, że wśród przeszkód ograniczających znaczący potencjał kraju, wymienić należy:

- wysokie wskaźniki cen na wszystkie rodzaje usług, w tym także transportowe, hotelowe i restauracyjne;

- niski poziom kontroli państwowej firm turystycznych, co przekłada się na brak nadzoru nad ich działalnością;

- niedostateczny rozwój infrastruktury transportowej i hotelowej;

- słabość, jeśli nie zupełny brak, bazy naukowo-badawczej, której przyświecałby cel poznania uwarunkowań rozwoju turystyki na terenie Kazachstanu;

- brak profesjonalnej kadry;

- niedoskonałość prawnego i gospodarczego stymulowania turystyki przyjazdowej i krajowej na poziomie państwowym i lokalnym;

- wąski asortyment oferowanych usług;

- terytorialna rozległość kraju;

- brak rozwiązania problemów wizowych i wiele innych.

Zaistniała sytuacja przypomina węzeł, który należy rozwiązywać stopniowo, wykorzystując światowe doświadczenia, ale kładąc jednocześnie akcent na specyfikę kraju. Minie jeszcze wiele czasu zanim turystyka zajmie trwałą i stabilną pozycję w gospodarce państwa, stając się jedną z wiodących gałęzi gospodarki narodowej. Jednakże obecnie państwo opracowuje długoi średniookresowe programy rozwoju turystyki. Trudno przewidzieć, kiedy zauważalne będą ich pierwsze rezultaty, ponieważ liczne programy już zakończono, a niezrealizowane zadania zostały przeniesione do kolejnych projektów. Kazachstan jest młodym, ambitnym państwem, dla którego konieczne jest myślenie o kompleksowym rozwiązaniu problemów wszystkich gałęzi gospodarki narodowej, ponieważ problemy w jednym z sektorów gospodarki w różnoraki sposób wpływają na rozwój innych sektorów, w tym na rozwój turystyki Kazachstanu.

Prawdopodobnie permanentne zmiany i transformacje $\mathrm{w}$ gospodarce światowej pociągną za sobą również działania na terytorium Kazachstanu. 
Zapewne kontynuowany będzie dalszy rozwój już ukształtowanych form turystyki wewnątrzkrajowej, ukierunkowanej na obsługę niedużych grup turystów, natomiast rozwój i doskonalenie wszystkich form turystyki w Republice Kazachstanu są mało realne.

\section{Perspektywy rozwoju turystyki w Kazachstanie}

W rządzie Republiki Kazachstanu w marcu 2013 r. dyskutowano o strategii rozwoju turystyki do 2020 r. Kazachski Instytut Rozwoju Przemysłu sugeruje, by zgodnie z obliczeniami zainwestować w turystykę około $10 \mathrm{mld}$ dolarów, przy czym inwestycje prywatne mają stanowić 55\% ogólnej sumy, tj. 5,5 mld dolarów. Narodowa Komisja Rozwoju Turystyki planuje, że udział sektora turystyki w PKB zwiększy się z 2,4 mld dolarów do 7 mld dolarów, a zatrudnienie wynosić będzie około 270 tys. osób (Postanowlenije Prazvitiel' stwa... 2013). Ministerstwo Spraw Zagranicznych Republiki Kazachstanu opracowuje program złagodzenia procedury wizowej. W roku 2014 planuje się zniesienie wiz dla obywateli 48 krajów, w tym 34 państw OECD i 14 innych, które nie stanowią jakiegokolwiek zagrożenia dla Kazachstanu.

Liczni analitycy są przekonani, że Kazachstan posiada wiele przyciągających uwagę, niepowtarzalnych walorów będących atrakcją tak dla turystów zagranicznych, jak i dla ludności miejscowej. W celu pokonania istniejących przeszkód dla rozwoju turystyki, swoją działalność wznowiła Rada Turystyki przy rządzie Republiki Kazachstanu. Członkowie Rady uważają, że rozwój turystyki jest procesem złożonym, wymagającym znaczących nakładów, lecz możliwym do zrealizowania. Obecnie działalność Rady Turystyki skoncentrowana jest na opracowaniu projektów klastrów turystycznych na terenie całej Republiki Kazachstanu.

W skład pierwszego klastra wejdzie Astana i jej okoliczne atrakcje: Burabaj, Korgałżyn, Karkarały, Zerenda, Kokczetaw, Bajanauł, gdzie przewiduje się rozwój turystyki miejskiej i przyrodniczej. Turystyka ekologiczna dominować będzie w obwodzie wschodniokazachstańskim, gdzie zaplanowano rozwój stref Katon-Karagaja i gór Zachodniego Ałtaju. Walory turystyczne Ałmaty i obwodu ałmackiego gwarantują rozwój turystyki narciarskiej i miejskiej (ERDAVLETOW, MUKATOWA i in. 2013). Na terytorium obwodu południowokazachstańskiego, kyzyłordyńskiego i żambylskiego pla- 
nowane jest stworzenie korzystnych warunków dla rozwoju turystyki kulturowej. Zachodni Kazachstan zostanie strefą turystyki wypoczynkowej (plażowej) z centrum w Kenderli, a także turystyki aktywnej. Obecnie rozwój programu klastrów opracowywany jest w trzech podstawowych projektach: rzeka Irtysz - Zbiornik Buchtarmiński - jezioro Zajsan; Katon-Karagaj - jezioro Markakol; Ridder - Ałataj - Góry Iwanowskie. Rozpatrywane jest także stworzenie dwóch dodatkowych klastrów: jezioro Ałakol i Semej - wycieczka na Pogórze Kazachskie. Każdy z nich jest wyjątkowy. Na przykład jezioro Ałakol (z języka kazachskiego - jezioro pstrokate) - to unikatowe miejsce na granicy obwodu ałmackiego i wschodniokazachstańskiego. Woda jest w nim słona i bardzo ciepła, z wysoką zawartością minerałów, a właściwości lecznicze ma również czarny żwir na brzegu jeziora. W centralnej części jeziora ulokowany jest archipelag składający się z trzech wysp objętych ochroną prawną jako Ałakolski Państwowy Rezerwat Przyrody. Wyspa Arałtobe jest jedynym miejscem na świecie, gdzie gnieżdżą się mewy reliktowe, gatunek wpisany do „Czerwonej Księgi”. Z kolei na płaskowyżu kanionu Żamanty znajduje się galeria petroglifów, radonowe jezioro Żałanaszkol, z leczniczymi błotami siarkowodorowymi. W sezonie letnim turystom oferuje się wycieczkę u podnóża gór Żabyktau (krańcowy odcinek gór Ałtaju Dżungarskiego). Poza licznymi zaletami ta strefa turystyczna cechuje się pewnymi niedogodnościami, z których za najistotniejszą należy uznać niską jakość dróg na odcinku $670 \mathrm{~km}$. I chociaż głównym wydarzeniem sezonu w czerwcu 2013 r. stał się czarterowy przejazd taborem kolejowym na trasie Ałmata-Dostyk, gwarantujący przyjazd turystów do miejsca wypoczynku, nie rozwiązało to wszystkich problemów tego regionu. Wśród kolejnych mankamentów wymienić należy brak domków wypoczynkowych umożliwiających komfortowy wypoczynek, świeżych produktów żywnościowych, placów zabaw dla dzieci, zagospodarowanych plaż i inne (ERDAWLETOW, ARTIEMEW $i$ in. 2013).

W zachodniej części Kazachstanu, w Aktau (obwód mangystauski), dyskusja nad projektem stworzenia międzynarodowego kurortu Kenderli trwa już od roku 2009, ale dopiero w kwietniu 2013 r. przedstawiciele Ministerstwa Przemysłu i Nowych Technologii zaproponowali systemowy plan rozwoju kurortu $\mathrm{w}$ ramach programu rozwoju turystyki w kraju do $2020 \mathrm{r}$. W klaster zachodniokazachstański, położony około $200 \mathrm{~km}$ od stolicy obwodu, o nazwie Riwiera Kaspijska, włączono wiele obiektów turystycznych. Zaplanowano budowę 4 tys. willi, 23 wysokiej klasy hoteli. Tematem towa- 
rzyszącym kształtowaniu specjalnych stref turystycznych na brzegu Morza Kaspijskiego jest likwidacja barier migracyjnych i wizowych. Na obszarze obwodu mangystauskiego znajduje się także unikatowy kompleks Aktau City, na terenie którego znajdują się domy mieszkalne, centra handlowo-rozrywkowe, medyczne, edukacyjne, biznesowe, wypoczynku i rozrywki, sieć hoteli, kurorty nadmorskie, przedsiębiorstwa opracowujące i realizujące projekty naftowe i gazowe. Należy podkreślić, że kompleks ten został zaprojektowany z uwzględnieniem potrzeb ludności miejscowej i wypoczywających, które zostały zidentyfikowane i określone na podstawie badań ankietowych, prowadzonych w Kazachstanie i poza jego granicami, m.in. w Rosji. Badania ankietowe uwzględniały różne kategorie wypoczywających (np. turystyka rodzinna, młodzieżowa). Realizację tych dwóch największych kompleksów (Kenderli i Aktau City) na terytorium Kazachstanu Zachodniego, licznie przyciągających turystów krajowych i zagranicznych, należy uznać za znaczące osiągnięcie w zakresie turystycznego rozwoju Kazachstanu.

Do rozwoju turystyki z opóźnieniem przystąpił obwód południowokazachstański. W roku 2012 przebywało tu zaledwie 115 zarejestrowanych turystów zagranicznych, chociaż samo mauzoleum hodży Ahmada Jasawi oficjalnie odwiedziło około 800 tys. osób w ciągu roku, a część z nich stanowili obcokrajowcy. Na obszarze tego regionu znajduje się wiele zabytków historycznych: mauzoleum Arystan-bab, ruiny miasta Otrar, mauzoleum Domałak-ana, święte źródła. Jednakże na potrzeby turystyki są one wykorzystywane $\mathrm{w}$ niewielkim zakresie, ponieważ przy ograniczonej dostępności komunikacyjnej tylko nieliczni turyści indywidualni docierają do wybranych obiektów. Zdarza się również często, że liczne biura turystyczne, biorąc pod uwagę niską jakość dróg krajowych, stan infrastruktury czy poziom obsługi, zachęcają swoich obywateli do wyjazdów poza granice kraju. Pomimo wykazanych mankamentów oficjalne organy zarządzające turystyką $\mathrm{w}$ obwodzie południowokazachstańskim są przekonane o przyśpieszonym rozwoju tego regionu. Wskazuje się, iż głównymi punktami klastra turystycznego są cztery regiony: tolebijski z trasami narciarskimi; sajramski gdzie rozwijać się będzie turystyka poznawcza i etniczna; Turkiestan - duchowa stolica Kazachstanu i Saryagasz z wodami mineralnymi i sanatoriami. 


\section{Regionalizacja terytorium Kazachstanu Południowego w celu rozwoju turystyki - studium przypadku}

Biorąc pod uwagę niedostrzeganie przez władze państwa roli, jaką odgrywają badania naukowe $\mathrm{w}$ planowaniu turystycznego rozwoju państwa czy regionu poniżej zostanie przedstawiona koncepcja turystycznej regionalizacji Kazachstanu Południowego.

Wzrost aktywności turystycznej i rekreacyjnej prowadzi do specjalizacji obszarów (ERDAWLETOW 2010). Rozwój turystyki, stworzenie i rozszerzenie jej bazy materialnej i technicznej, intensywne wykorzystanie walorów przyrodniczych i kulturowo-historycznych $\mathrm{w}$ celach turystycznych, a także zwiększenie jej wpływu na życie społeczne i ekonomiczne regionów skłaniają do specjalnego podejścia $\mathrm{w}$ badaniach terenu pod kątem regionalizacji turystycznej. Regionalizacja obszaru, będąca jedną z metod badań geograficznych, stanowi podstawę planowania terytorialnego, podniesienia efektywności prognozowania i zarządzania. $W$ literaturze przedmiotu znane są próby opracowania zasad i metodologii regionalizacji w celach turystycznych i rekreacyjnych zarówno w skali całego kraju, jak i w poszczególnych regionach. Jednakże na razie nie ma wspólnych, akceptowanych przez większość naukowców, zasad metodycznych takiej regionalizacji.

Większość podejmowanych prac, związanych z problemem regionalizacji polega na pojmowaniu regionu turystycznego jako obszaru cechującego się istnieniem potencjału turystycznego i rekreacyjnego, bowiem to właśnie tereny posiadające walory turystyczne i rekreacyjne (przyrodnicze lub antropogeniczne) są korzystne dla organizacji wypoczynku i turystyki.

Regionalizacja pozwala zgromadzić informacje wyjściowe o rosnących potrzebach ludzi na obszarach ekologicznych, a także o zasobach, dzięki którym można te potrzeby zaspokoić. Oprócz tego regionalizacja stwarza możliwość skoncentrowania i zróżnicowania informacji turystycznej o osobliwościach przyrodniczych, kulturowo-historycznych danej okolicy.

Regionalizacja opiera się na wykorzystaniu jednego lub kilku kryteriów. Na przykład kryteriami regionalizacji terytorium Rumunii były walory turystyczne i rekreacyjne przyrodnicze oraz antropogeniczne. Innym przykładem regionalizacji, której podstawą był potencjał przyrodniczo-rekreacyjny jest Bułgaria.

W badaniach naukowych oraz przy projektowaniu systemów rekreacyjnych często przyjmowane są metody inwentaryzacji walorów przyrod- 
niczych dla rekreacji i turystyki. Rejestr ilościowy i ocena walorów turystycznych i rekreacyjnych, a także analiza działających przedsiębiorstw turystycznych pozwala na przeprowadzenie regionalizacji. Jej metodyka polega na opracowaniu skal pomiarowych. Jak zauważają N.S. MIRONIENKO i I.T. TWIERDOCHLIEBOW (1981), przygotowanie skal pomiarowych ma charakter syntetyczny, ponieważ zawarta jest w nich ocena. Obecnie najczęściej wykorzystywane są cztery rodzaje skal: skala klasyfikacji (nominalna), porządkowa, interwałowa i skala ilorazowa.

Wykorzystując doświadczenie różnych krajów, podjęta została próba regionalizacji terytorium Kazachstanu Południowego według stopnia nasycenia walorami turystycznymi i rekreacyjnymi (przyrodniczymi i antropogenicznymi) oraz wyposażenia w obiekty obsługi ruchu turystycznego.

Regionalizacja oparta została na analizie walorów turystycznych i rekreacyjnych, z uwzględnieniem istniejącego i planowanego zagospodarowania turystycznego $\mathrm{w}$ granicach administracyjno-terytorialnych Kazachstanu Południowego.

Podział administracyjny wybrany został nieprzypadkowo. Po pierwsze, jest istotny dla wygody szczegółowej analizy informacji statystycznych. Po drugie, $w$ granicach administracyjnych prowadzone są spisy ludności aktywnej zawodowo. W tych regionach, które nie mają warunków do lokowania i rozwoju współczesnego przemysłu lub działalności rolniczej, organizacja turystyki może stać się stymulatorem rozwoju ekonomicznego i sprzyjać zmniejszeniu bezrobocia. Po trzecie, wydzielenie regionów, które cechują się korzystnymi warunkami do rozwoju turystyki, pozwoli władzom lokalnym podjąć środki na ich zachowanie. Po czwarte, środki finansowe przeznaczane na rozwój turystyki w Kazachstanie Południowym, będą wykorzystywane w jego granicach administracyjnych (ALIJEWA 2001).

W pracy wykorzystano skalę interwałową. Odległości na skali interwałowej przyjmowane są umownie, po wskazaniu wartości minimalnych i maksymalnych dla analizowanego obszaru. Różnicę między tymi wartościami stanowi interwał podziału dla każdego stopniowania. Maksymalna zawartość informacji przy przyjętej liczbie stopniowania otrzymywana jest przy równomiernym podziale skali na interwały.

Warto podkreślić, że każdemu obiektowi przyznany został jeden punkt. Suma punktów, zidentyfikowanych za pomocą mapy krajobrazowej i przyporządkowanych do każdego obiektu, wskazuje na liczbę punktów, według których oceniane są warunki przyrodnicze każdego okręgu, czy regionu. 
W rezultacie przeprowadzonych badań otrzymano ocenę obszaru według stopnia nasycenia walorami przyrodniczymi (turystycznymi i rekreacyjnymi). Wyniki przedstawiają się następująco: liczbę punktów powyżej 151 przyznano obwodowi ałmackiemu, 101-150 - obwodowi południowokazachstańskiemu, 51-100 - obwodowi żambylskiemu, 0-50 - obwodowi kyzyłordyńskiemu. Tak więc obwód, który posiada maksymalną liczbę punktów, ma najkorzystniejsze warunki przyrodnicze do rozwoju turystyki. Jest to obwód wysokiej przydatności do uprawiania turystyki i rekreacji (ponad 151); obwód, w którym liczba punktów waha się w przedziale 101-150 - jest średniej przydatności; obwód, posiadający od 51 do 100 punktów - to obszar niewysokiej przydatności; regiony z minimalną liczbą punktów 0-50 są określane jako obszary niskiej przydatności walorów przyrodniczych do uprawiania turystyki i rekreacji.

Południowy Kazachstan ma najkorzystniejsze warunki do rozwoju turystyki. Tutaj koncentruje się znaczna liczba walorów turystycznych i rekreacyjnych, tak przyrodniczych, jak i społeczno-ekonomicznych, przy czym większość z nich jest niepowtarzalna w skali kraju. Zaliczyć do nich należy Kanion Szaryński, reliktowy gaj jesionowy, śpiewający barchan, jeziora Kołsajskie, jezioro Kajyngdy, a także liczne zabytki kulturowo-historyczne, takie jak kurhany Bes-Szatyr, petroglify Tamgały-Tas, kurhan Issyk, mauzoleum hodży Ahmada Jasawi, mauzoleum Arystan-Bab, mauzoleum Babadżi-Chatun i Ajsza-Bibi oraz liczne inne obiekty turystyczne.

Zatem analizując walory antropogeniczne (turystyczne i rekreacyjne) Południowego Kazachstanu można ocenić to terytorium według stopnia nasycenia walorami kulturowo-historycznymi, turystycznymi i rekreacyjnymi. Liczba punktów powyżej 400 przyznana została obwodowi ałmackiemu, od 301 do 400 - obwodowi południowokazachstańskiemu, od 201 do 300 - obwodowi żambylskiemu; poniżej 200 - obwodowi kyzyłordyńskiemu. Tak więc obwód ałmacki, cechujący się największą liczbą punktów, można zaliczyć do obszarów wysokiej przydatności walorów antropogenicznych do rozwoju turystyki i rekreacji. Obwód południowokazachstański, któremu przyznano od 300 do 400 punktów, ma ogólnie korzystne warunki i należy do obszarów średniej przydatności; obwód żambylski, który uzyskał 201 -300 punktów jest obszarem niewysokiej przydatności, zaś obwód kyzyłordyński zaliczony została do obszarów niskiej przydatności.

Jeśli chodzi o infrastrukturę turystyczną, to powinna być taka, aby zaspokajać rosnący popyt $\mathrm{w}$ miejscach istniejących walorów turystycznych i rekreacyjnych, wpływać na kształtowanie ruchu turystycznego, a także 
równomiernie rozkładać i ukierunkowywać ruch turystyczny w stosunkowo słabo poznane regiony.

Infrastruktura turystyczna Kazachstanu Południowego jest bardziej rozwinięta $\mathrm{w}$ porównaniu $\mathrm{z}$ innymi regionami kraju. Wytłumaczyć to można tym, że region ten jest najbardziej znany wśród turystów, do czego przyczyniają się korzystne warunki klimatyczne i orograficzne oraz bliskość liczącego 1,5 mln ludności, miasta Ałmaty.

W rezultacie analizy infrastruktury turystycznej Kazachstanu Południowego dokonano oceny terytorium według stopnia wyposażenia w nią. Liczbę punktów powyżej 80 uzyskał obwód ałmacki, od 71-80 obwód południowokazachstański, 61-70 obwód kyzyłordyński, poniżej 60 obwód żambylski. Tak więc najkorzystniejszy do rozwoju turystyki jest obwód ałmacki, który ma najbardziej rozwiniętą sieć infrastruktury turystycznej wysokiej przydatności. Obwód południowokazachstański, który znalazł się w przedziale od 71 do 80 punktów, zaliczony został do obszarów o średniej przydatności i dysponuje korzystnymi warunkami dla rozwoju turystyki. Obwód kyzyłordyński, którego liczba punktów waha się od 61 do 70, ma przyznaną kategorię niewysokiej przydatności. Obwód żambylski, liczący poniżej 60 punktów, jest obszarem o niskiej przydatności.

Wszystkie otrzymane rezultaty prezentuje tab. 1. Dla każdego obwodu określono jego potencjał według:

- przyrodniczych walorów turystycznych i rekreacyjnych;

- antropogenicznych walorów turystycznych i rekreacyjnych;

- wyposażenia w infrastrukturę turystyczną.

Dla wygody obliczeń ogólnego potencjału turystycznego i rekreacyjnego każdej kategorii, w porządku rosnącym, były przyporządkowane punkty od 1 do 4 .

Zgodnie z przyjętą zasadą, dowolna ocena ilościowa jednego lub kilku walorów turystycznych i rekreacyjnych powinna prowadzić do określenia ich ogólnego (sumarycznego) potencjału. Ogólny (sumaryczny) potencjał turystyczny i rekreacyjny - to kompleksowy wskaźnik sumaryczny, charakteryzujący możliwości rozwoju turystyki na obszarze Kazachstanu Południowego.

Sumaryczny potencjał turystyczny i rekreacyjny każdego obwodu określony jest jako suma punktów odzwierciedlająca stopień nasycenia walorami przyrodniczymi, antropogenicznymi, turystycznymi i rekreacyjnymi, oraz wyposażenia w infrastrukturę turystyczną. 
Podsumowanie sumarycznego potencjału turystycznego i rekreacyjnego zaprezentowano $\mathrm{w}$ tab. 2.

Tabela 1. Regionalizacja terytorium Kazachstanu Południowego wykonana w celu oceny rozwoju turystyki

\begin{tabular}{|c|c|c|c|}
\hline \multicolumn{3}{|c|}{ Regionalizacja Kazachstanu Południowego według stopnia } & \multirow{3}{*}{$\begin{array}{c}\text { Kategorie } \\
\text { - liczba punktów }\end{array}$} \\
\hline \multicolumn{2}{|c|}{$\begin{array}{c}\text { nasycenia walorami turystycznymi } \\
\text { i rekreacyjnymi }\end{array}$} & \multirow{2}{*}{$\begin{array}{c}\text { wyposażenia } \\
\text { w infrastrukturę } \\
\text { turystyczną }\end{array}$} & \\
\hline przyrodniczymi & antropogenicznymi & & \\
\hline Obwód ałmacki & obwód ałmacki & obwód ałmacki & $\begin{array}{l}\text { wysoka przydatność } \\
-4 \text { punkty }\end{array}$ \\
\hline $\begin{array}{l}\text { Obwód południowo- } \\
\text { kazachstański }\end{array}$ & $\begin{array}{l}\text { obwód południowo- } \\
\text { kazachstański }\end{array}$ & $\begin{array}{l}\text { obwód południowo- } \\
\text { kazachstański }\end{array}$ & $\begin{array}{l}\text { średnia przydatność } \\
-3 \text { punkty }\end{array}$ \\
\hline Obwód żambylski & obwód żambylski & obwód kyzyłordyński & $\begin{array}{l}\text { niewysoka przydatność } \\
-2 \text { punkty }\end{array}$ \\
\hline Obwód kyzyłordyński & obwód kyzyłordyński & obwód żambylski & $\begin{array}{c}\text { niska przydatność } \\
-1 \text { punkt }\end{array}$ \\
\hline
\end{tabular}

Źródło: opracowanie własne.

Tabela 2. Sumaryczny walorowy i turystyczny potencjał rozwoju turystyki Kazachstanu Południowego

\begin{tabular}{|c|c|c|c|c|}
\hline \multirow{3}{*}{ Region } & \multicolumn{3}{|c|}{ Punkty według stopnia } & \multirow{3}{*}{$\begin{array}{c}\text { Suma } \\
\text { punktów }\end{array}$} \\
\hline & \multicolumn{2}{|c|}{$\begin{array}{c}\text { nasycenia walorami turystycznymi } \\
\text { i rekreacyjnymi }\end{array}$} & \multirow{2}{*}{$\begin{array}{c}\text { wyposażenia } \\
\text { w infrastrukturę } \\
\text { turystyczną }\end{array}$} & \\
\hline & przyrodniczymi & antropogenicznymi & & \\
\hline Obwód ałmacki & 4 & 4 & 4 & 12 \\
\hline $\begin{array}{l}\text { Obwód południowo- } \\
\text { kazachstański }\end{array}$ & 3 & 3 & 3 & 9 \\
\hline Obwód żambylski & 2 & 2 & 1 & 5 \\
\hline Obwód kyzyłordyński & 1 & 1 & 2 & 4 \\
\hline
\end{tabular}

Źródło: opracowanie własne.

W celu oceny sumarycznego potencjału turystycznego i rekreacyjnego była przygotowana skala uogólniająca, także uporządkowana według interwałów, oraz opracowano kartogram „Sumaryczny walorowy i turystyczny potencjał rozwoju turystyki Kazachstanu Południowego" (rys. 1), który po- 
kazuje, że wysoki potencjał (12) ma obwód ałmacki. Przyznana mu została maksymalna liczba punktów - 4. Średni potencjał (9) ma obwód południowokazachstański. Odpowiada mu średnia liczba punktów - 3. Niewysoki potencjał (5) ma obwód żambylski, który otrzymał 2 punkty. Niski potencjał (4) ma obwód kyzyłordyński, któremu przyznano 1 punkt.

Przeprowadzona regionalizacja pozwoliła na ocenę potencjału turystycznego i rekreacyjnego Kazachstanu Południowego i uporządkowanie obwodów regionu według stopnia przydatności walorów do rozwoju rekreacji i turystyki. W efekcie ogólnej oceny walorów turystycznych i rekreacyjnych regionu udowodniono, że najlepsze warunki dla rozwoju turystyki ma obwód ałmacki.

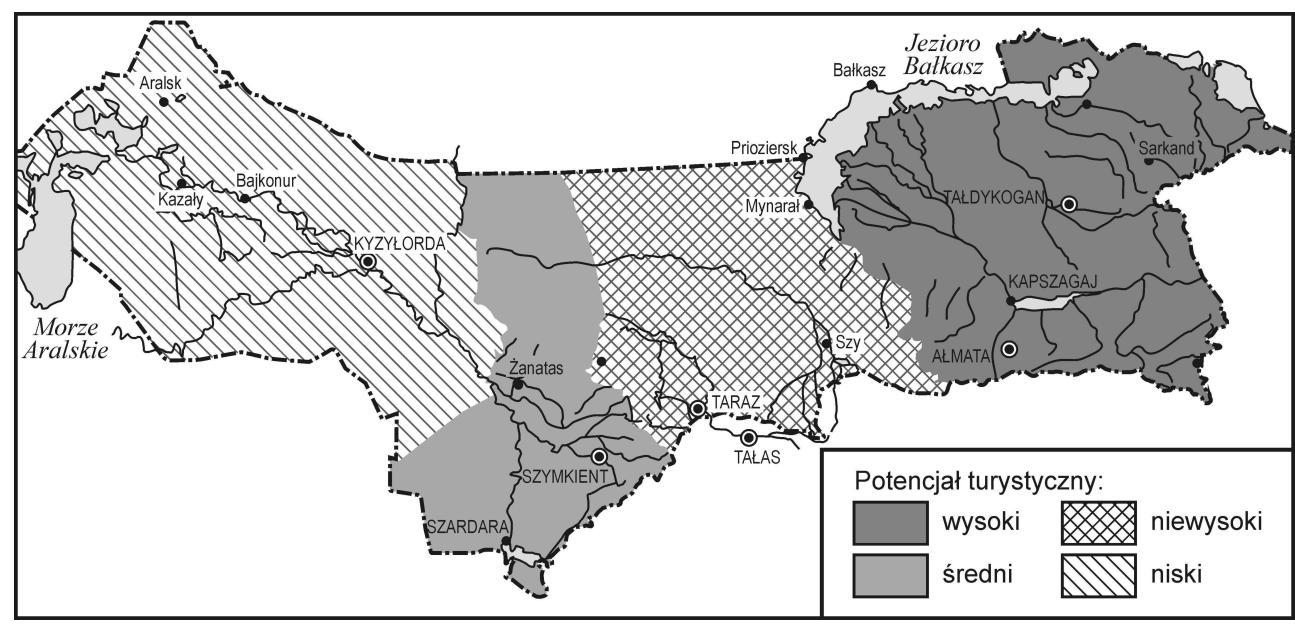

Rys. 1. Zróżnicowanie potencjału turystycznego Kazachstanu Południowego (ujęcie sumaryczne)

Źródło: opracowanie własne

W wyniku badań wykazano, że cały Kazachstan Południowy posiada duży potencjał do rozwoju turystyki, co potwierdza obecność zarówno znacznej liczby walorów przyrodniczych (turystycznych i rekreacyjnych) oraz antropogenicznych (turystycznych i rekreacyjnych), jak również zagospodarowanie turystyczne. 


\section{Podsumowanie}

W opinii ekspertów, Republika Kazachstanu jest niedostatecznie atrakcyjna dla turystów zagranicznych, nie nadąża z przygotowaniem obsługi ruchu turystycznego na odpowiednim poziomie, nie wytrzymuje konkurencji z firmami zagranicznymi w żadnej z usług sektora turystycznego. W roku 2011 udział turystów kazachstańskich w ogólnym ruchu turystycznym w Kazachstanie stanowił 79,5\%. Spośród turystów zagranicznych najliczniej przybyli obywatele Federacji Rosyjskiej (4,8\% ogólnego ruchu turystycznego), a następnie Wielkiej Brytanii i Irlandii Północnej $(2,4) \%)$, USA (1,6\%), Turcji $(1,4 \%)$, Włoch $(1,3 \%)$, Chin i Niemiec (po $0,9 \%)$, Holandii $(0,8 \%)$ i z pozostałych krajów (6,4\%).

W Republice Kazachstanu brakuje jednolitego przemysłu turystycznego. Rozwijają się pojedyncze dziedziny, praktycznie niepowiązane ze sobą, w każdej z nich są pewne braki, usterki, ale jednocześnie i pozytywy.

Znaczne szanse rozwoju turystyki związane są z organizacją targów EXPO 2017. W opinii specjalistów zarządzających turystyką Ałmaty, podsta-wowym ich zadaniem jest przyciągnąć do kraju licznych gości. W celu organizacji tego przedsięwzięcia wymagane są olbrzymie inwestycje, ukierunkowane na przygotowanie obiektów targowych i hotelowych, co pociąga za sobą stworzenie nie mniej niż 1000 nowych miejsc pracy. Goście, którzy przyjadą do Astany będą mieli możliwość zapoznania się z kulturą i tradycjami Kazachstanu.

Analizując natomiast obecny stan rozwoju turystyki w Kazachstanie Południowym można zauważyć, że według głównych wskaźników, takich jak liczba firm turystycznych, liczba obsłużonych przez nich turystów, liczba miejsc noclegowych (ti. obecność hoteli, moteli, kempingów, baz turystycznych, domów gościnnych, domów wypoczynkowych, pensjonatów i innych budynków oraz obiektów wykorzystywanych podczas krótkookresowego pobytu gości i w celu ich obsługi), region ten zajmuje pozycję lidera w kraju.

Zgodnie z oficjalnymi danymi Agencji Statystycznej Republiki Kazachstanu, w 2012 r. liczba firm turystycznych w Kazachstanie wynosiła 1994. Z tej liczby 1129 firm turystycznych skoncentrowanych było w Kazachstanie Południowym (w mieście Ałmaty - 954, w obwodzie ałmackim - 49, w obwodzie żambylskim - 27, w południowokazachstańskim - 89, w kyzyłordyńskim - 10) (Turizm Kazachstana 2008-2012).

W 2012 r. firmy turystyczne w Kazachstanie obsłużyły 641302 osoby, z czego prawie połowę (295 360 osób) w Kazachstanie Południowym. 
Liczba obiektów noclegowych w Kazachstanie 2012 r. wynosiła 1526, z czego 1/3 (451 obiektów) skoncentrowana była w Kazachstanie Południowym (Turizm Kazachstana 2008-2012). Należy zauważyć stały i sukcesywny wzrost znaczenia turystyki w Kazachstanie Południowym. W 2011 r. w mieście Ałmaty odbyły się siódme zimowe igrzyska azjatyckie. Zakrojona na szeroką skalę organizacja takiej imprezy sportowej, jaką są igrzyska azjatyckie, pozwoli w przyszłości pretendować do organizacji w mieście Ałmaty zimowych igrzysk olimpijskich.

\section{BIBLIOGRAFIA}

AlIJEWA Ż.N., 2001, Rol' ekotogiczeskogo turizma w ustojcziwom razwitii Riespubliki Kazachstan (na primierie Atmatinskoj obtaski), Awtorief diss. kand. gieogr. nauk: 11.00.02., Ałmaty.

ERDAWLETOW S.R., 2010, Giegrafija turizma, Ałmaty.

ERDAWLETOW S.R., ARTEMEW A.M. i in., 2013, Problemy i pierspiektiwy razwitija Atakol'skoj riekrieacionnoj zony. Wozmożnosti razwitija krajewiedienija i turizma Sibirskogo riegiona i sopriediel'nych tierritorij, Tomsk, s. 92-97.

ERDAWLETOW S.R. i in., 2013, K woprosu naucznogo obiespieczenija razwitija turizma Kazachstana. Nowaja industrializacija: fitosofskije, ekonomiczeskije, socijal'nyje, ekotogiczeskije, politiczeskije aspiekty, Sankt-Peterburg, s. 13-17.

ERDAWLETOW S.R., MUKATOWA D.M. i in., 2013, Atmaty - mieżdunarodnyj turistskij centr, "Mieżdunarodnyj żurnał prikładnych i fundamiental'nych issliedowanij", № 9, s. 100-104.

MIRONIENKO N.S., TWIERDOCHLEBOW I.T., 1981, Riekrieacionnaja gieografija, M.: MGU Turizm Kazachstana 2008-2012, Statisticzeskij sbornik; http://www.stat.kz/publishing/20131/Туризм\%20 2008-2012гг\%20интерактив.pdf.

Postanowlenije Prawitiel'stwa Riespubliki Kazachstan „Ob utwierżdienii Koncepcii razwitija turistskoj otrasli Respubliki Kazachstan do 2020 goda" ot 28 fiewralia 2013 goda, № 192.

Zakon O turistskoj diejatiel'nosti w Riespublikie Kazachstan, 2001, „Kazachstanskaja prawda”, № 27, Ałmaty.

Ttumaczenie z języka rosyjskiego: Armina Muszyńska

\section{MODERN KAZAKHSTAN - A NEW DIRECTION ON THE GLOBAL TOURISM MARKET}

Key words: the Republic of Kazakhstan, tourism policy, tourist assets, recreational assets, tourism potential, tourism cluster, tourist valorization, tourism regionalization

\section{Summary}

- The article is an attempt to present Kazakhstan - a country with a wide variety of tourist assets - as a new destination on the global tourism market. Unfortunately, tourist assets alone are not enough 
to make it an important area on the tourist map of the world, neither for foreign nor domestic tourists. Apart from assets, it needs to develop suitable tourist infrastructure (accommodation and catering facilities, transport system) and high standard services in order to attract foreign tourists and encourage its own citizens to travel around and rest in Kazakhstan. At present, the unsatisfactory tourism development in Kazakhstan results in small numbers of foreign tourists and makes its citizens search for recreation opportunities abroad.

The authors point to the fact that tourism development in Kazakhstan is so seriously affected by the lack of a coherent and consistent tourism policy at the national and regional level, as well as the lack of adequate information and promotion, that it is impossible to speak of the international significance of this country. Moreover, it should be stressed that there are too few research centres or "laboratories" in Kazakhstan dealing with the issue of the tourism development conditions and tourism forecasting.

However, a positive symptom of the state's involvement in the problem of tourism is the designing and creating of tourism clusters in various regions of the country, as well as the hope to stimulate regions of exceptional tourist assets but economically underdeveloped.

Considering the fact that state authorities underestimate the role of scientific research in the tourism development of a country or region, the article ends with the regionalization of the South Kazakhstan territory for tourism development purposes.

Ttumaczenie: Ewa Mossakowska 